\title{
Evaluation of symptoms, radiological findings, laboratory data and outcome in COVID-19 patients with chronic kidney disease at Tehran, Iran
}

\section{Yasaman Sadat Keshmiri}

Shahid Beheshti University of Medical Sciences

\section{Sina Khosravi Mirzaie}

Shahid Beheshti University of Medical Sciences

Shahnaz Sali ( $\square$ dr.shsali@gmail.com )

Shahid Beheshti University of Medical Sciences

Davood Yadegarynia

Shahid Beheshti University of Medical Sciences

\section{Sara Abolghasemi}

Shahid Beheshti University of Medical Sciences

Shabnam Tehrani

Shahid Beheshti University of Medical Sciences

\section{Amir Zamani}

Shahid Beheshti University of Medical Sciences

\section{Mohamad Mehdi Derisi}

Shahid Beheshti University of Medical Sciences

\section{Research Article}

Keywords: COVID19, chronic kidney disease (CKD), Dialysis, Transplant

Posted Date: May 6th, 2021

DOl: https://doi.org/10.21203/rs.3.rs-101128/v3

License: (c) (1) This work is licensed under a Creative Commons Attribution 4.0 International License. Read Full License

Version of Record: A version of this preprint was published at Journal of Microbiology and Infectious Diseases on November 3rd, 2020. See the published version at https://doi.org/10.5799/jmid.993902. 


\section{Evaluation of symptoms, radiological findings, laboratory data and outcome in COVID-19 patients with chronic kidney disease at Tehran, Iran}

1. Yasaman Sadat Keshmiri

Affiliation: Student Research Committee, School of Medicine, Shahid Beheshti University of Medical Sciences, Tehran, Iran

E-mail: Yk1376@gmail.com

2. Sina Khosravi Mirzaie

Affiliation: Student Research Committee, School of Medicine, Shahid Beheshti University of Medical Sciences, Tehran, Iran

E-mail: Sinakhosravi1997@gmail.com

3. Shahnaz Sali

Affiliation: Infectious Diseases and Tropical Medicine Research Center, Shahid Beheshti University of Medical Sciences, Tehran, Iran.

E-mail: dr.shsali@gmail.com

4. Davood Yadegarynia

Affiliation: Infectious Diseases and Tropical Medicine Research Center, Shahid Beheshti University of Medical Sciences, Tehran, Iran.

E-mail: $\underline{\text { d.yadegarynia@gmail.com }}$

5. Sara Abolghasemi

Affiliation: Infectious Diseases and Tropical Medicine Research Center, Shahid Beheshti University of Medical Sciences, Tehran, Iran

E-mail:a59sara@yahoo.com

6. Shabnam Tehrani

Affiliation: Infectious Diseases and Tropical Medicine Research Center, Shahid Beheshti University of Medical Sciences, Tehran, Iran

E-mail: shabnam89@yahoo.com

7. Amir Zamani

Affiliation: Student Research Committee, School of Medicine, Shahid Beheshti University of Medical Sciences, Tehran, Iran

E-mail: Zamani.amir44@gmail.com

8. Mohamad Mehdi Derisi

Affiliation: Student Research Committee, School of Medicine, Shahid Beheshti University of Medical

Sciences, Tehran, Iran

E-mail: Derisi.mohamad@yahoo.com 
*Corresponding Author

Shahnaz Sali

Affiliation: Infectious Diseases and Tropical Medicine Research Center, Shahid Beheshti University of Medical Sciences, Tehran, Iran.

E-mail: dr.shsali@gmail.com

Phone number: +98 9123067784

ORCID:

Fax: +98212254 6026

Address: Labbafinezhad hospital, 9th Boostan St, Tehran, Tehran Province, Iran 


\section{Introduction}

Today's world is facing a huge wave of COVID-19 virus disease. Thirty years after the virus was first discovered in the 1930s, evidence of its pathogenicity has been established in humans (1). In December 2019, a viral outbreak of the same family was reported from Wuhan, China $(2,3)$, and the spread of the disease has since infected more than 14 million people and killed more than 600,000 worldwide (4).

The presence of underlying diseases such as diabetes, hypertension, cardiovascular disorders as well as COPD can affect the severity of the disease in different people and the mortality rate (5 7). Chronic kidney disease (CKD) is a common disease that can lead to impaired renal function by reducing the glomerular filtration rate (GFR) (8). Statistics show that in 2017, over 5 million patients worldwide were suffering from the disease (9). Old age and the presence of underlying diseases in most patients with this disease are among the factors that make CKD patients more susceptible to COVID-19.

In $\mathrm{CKD}$, the glomerular filtration rate decreases due to a decrease in the number of nephrons. Adaptive responses are then generated by factors such as vasoactive hormones, growth factors, and cytokines (8). The presence of cytokines causes a cytokine storm, activating the angiotensin II pathway, which eventually leads to increased blood coagulation and microangiopathy (10). Studies have shown that ICU hospitalization rates, as well as mortality in CKD patients, are significantly higher due to symptoms such as cough, severe shortness of breath, and extreme fatigue $(11,12)$. Also, the results of laboratory tests of these patients have shown that ferritin and CRP in CKD patients are associated with a significant increase, which can be related to their severe inflammatory status (13).

Despite a large number of CKD patients, research in this area has been relatively largely neglected. In this study, we describe 78 patients in the Labafinejad Hospital in Tehran, Iran. Clinical manifestations, radiological findings, laboratory data, and results are reviewed to provide insights for physicians in managing patients with chronic kidney disease infected with COVID-19.

\section{Material and methods}

\section{Study design}

This study, which is designed as a cross-sectional study from March 2, 2020, to May 9, 2020, has been approved by the Ethics Committee in Biomedical Research of Shahid Beheshti University of Medical Sciences with the code (IR.SBMU.REC.1399.018). Patients with novel coronavirus (COVID-19) referred to Labbafinezhad Hospital in Tehran were included in the study if they met the inclusion criteria (cough, fever, fatigue, myalgia, chest pain, dyspnea, other upper respiratory symptoms, and gastrointestinal symptoms).Diagnosis of COVID-19 patients was based on the WHO interim guidance, a confirmed COVID-19 patient defined as an individual with a positive reverse transcriptase-polymerase chain reaction (RT-PCR) result or a patient with common COVID-19 symptoms and a computed tomography scan (CT-scan) compatible to COVID-19 pattern confirmed by experts [14].The written informed consent form was obtained from all patients by the Ethics Commission of the hospital. 
A total of 91 patients presented within the specified time period, out of 78 patients who were eligible for the study. Patients are divided into 4 subgroups (fig 1):

1) patients who were not on dialysis

2) patients on maintenance dialysis

3) patients who underwent dialysis following COVID-19 and

4) patients with a history of a kidney transplant.

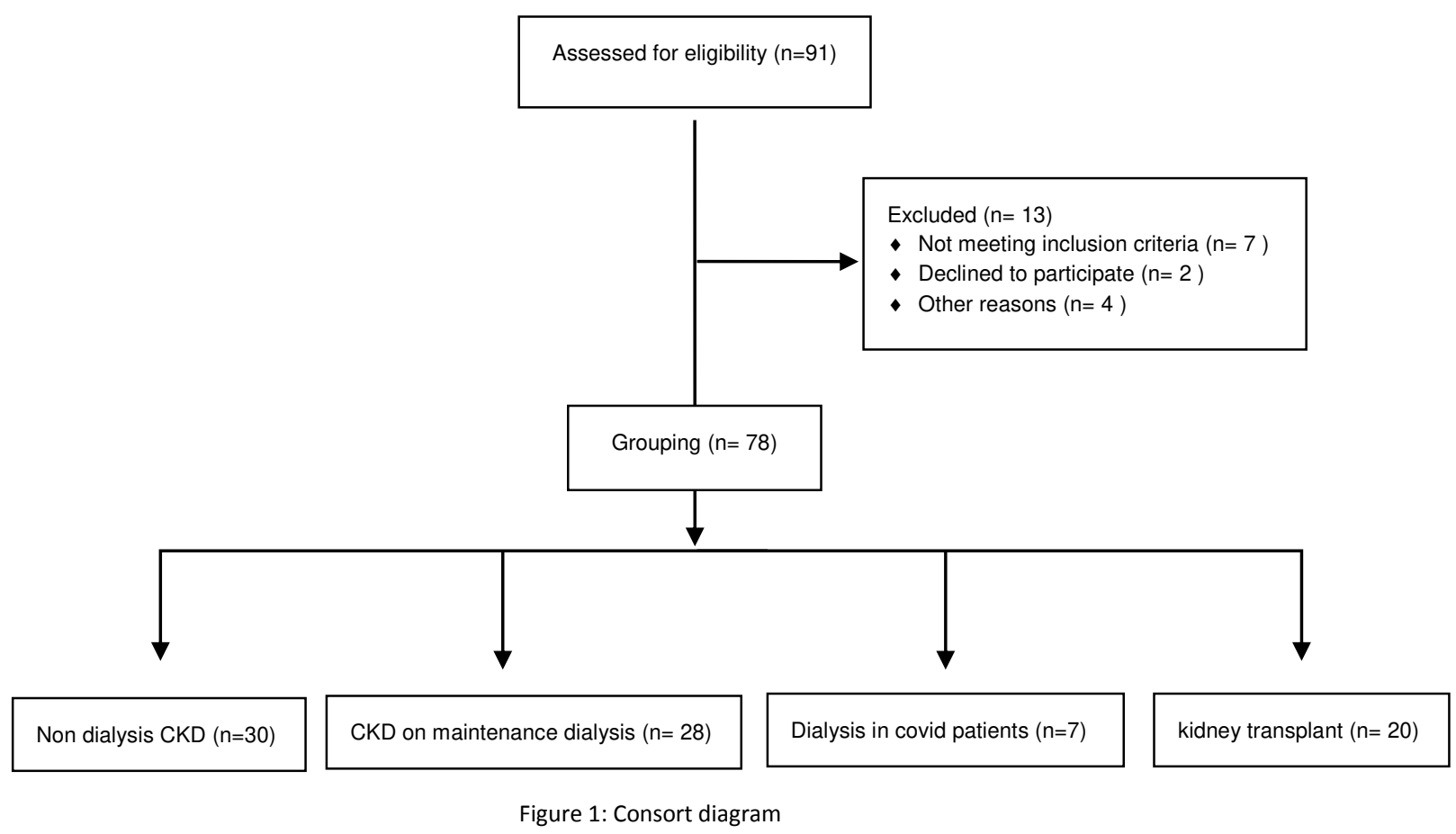

After reviewing clinical charts, nursing records, laboratory findings, radiological reports and other medical records of CKD patients with COVID-19 confirmed infection, clinical presentation, laboratory data, radiology findings and results were extracted from documented medical records using data collection forms. laboratory tests were performed again before discharge. The quick COVID-19 Severity Index (qCSI) was used to assess the severity of COVID-19 in patients. The qCSI ultimately requires only 3 variables, all of which are accessible at the bedside [26].

\section{Statistical Analysis}

The collected data were summarized as descriptive profiles by using mean, median, standard deviation, and variance. The percentage, mean, median, standard deviation of patients were calculated within different groups for specific variables. Independent t-test, paired t-test, and chisquare were used to compare the clinical features of patients with COVID-19. A P. value of less than 0.05 was considered to indicate statistical significance. All the statistical analyses were performed by the Statistical Package for Social Sciences (SPSS Inc., Chicago, Illinois, USA) version 26.0 . 


\section{Result}

Based on the results in Table 1, of the 78 patients studied, $53(68.8 \%)$ were female. The average age of patients was 64.04 years (32-96). Among the included patients, 23 (29.48\%) were not on dialysis, $28(35.89 \%)$ were on maintenance dialysis, $7(8.97 \%)$ underwent dialysis following COVID-19 and 20 (8.97\%) patients had a history of a kidney transplant. Hypertension (72.5\%), diabetes $(63.8 \%)$ and Cardiovascular disease $(38.2 \%)$ were the ost common among patients, respectively. Among all participants, 40 (52.6\%) patients died. The most common symptom was dyspnea (56.6\%), followed by dry cough (38.7\%). Quick COVID_19 severity index (qCSI) results show $35.7 \%$ of patients were in the low intermediate group which means they have had a $30 \%$ chance of critical illness. $28.2 \%$ of patients were in the high intermediate category, which means they have had a $44 \%$ risk of critical illness.

Table 1. Clinical and demographic features of patients based on renal therapy

\begin{tabular}{|c|c|c|c|c|c|c|c|c|c|c|c|}
\hline Variables & Total & $\mathbf{T}(\mathrm{M})$ & $\begin{array}{c}\text { Non dialysis } \\
\text { CKD } \\
(n=23)\end{array}$ & $\mathrm{T}(\mathrm{M})$ & $\begin{array}{c}\text { CKD on maintenance } \\
\text { dialysis }(n=28)\end{array}$ & $\mathrm{T}(\mathrm{M})$ & $\begin{array}{c}\text { Dialysis in covid } \\
\text { patients }(n=7)\end{array}$ & $\mathrm{T}(\mathrm{M})$ & $\begin{array}{c}\text { KT } \\
(\mathrm{N}=20)\end{array}$ & $\mathrm{T}(\mathrm{M})$ & p-value \\
\hline Age $($ mean \pm SD $)$ & $64.4+15.03$ & 76 & $65.90+\_12.39$ & $23(1)$ & $9 \Lambda / \Upsilon^{9}+\ldots 14.82$ & $28(1)$ & $62.00+\_22.62$ & $7(0)$ & 57.00+_13.29 & $20(0)$ & 0.069 \\
\hline $\begin{array}{ll}\text { Sex } & \\
& \text { Male (\%) } \\
& \text { Female (\%) } \\
\end{array}$ & $\begin{array}{l}24(31.2 \%) \\
53(68.8 \%)\end{array}$ & 77 & $\begin{array}{c}6(26.1 \%) \\
17(73.9 \%)\end{array}$ & $23(0)$ & $\begin{array}{c}5(18.5 \%) \\
22(81.5 \%)\end{array}$ & $27(1)$ & $\begin{array}{l}3(42.5 \%) \\
4(57.1 \%) \\
\end{array}$ & $7(0)$ & $\begin{array}{l}10(50 \%) \\
10(50 \%) \\
\end{array}$ & $20(0)$ & 0.111 \\
\hline $\begin{array}{l}\text { Initial symptoms } \\
\text { Fever } \\
\text { Chills } \\
\text { Dry cough } \\
\text { Dyspnea } \\
\text { GI symptoms }\end{array}$ & $\begin{array}{l}22(30.1 \%) \\
10(13.2 \%) \\
29(38.7 \%) \\
43(56.6 \%) \\
19(25 \%)\end{array}$ & $\begin{array}{l}0 \\
\dot{r} \\
\dot{r} \\
\dot{r}\end{array}$ & $\begin{array}{c}8(34.8 \%) \\
2(8.7 \%) \\
9(39.1 \%) \\
15(65.2 \%) \\
6(26.1 \%)\end{array}$ & $\begin{array}{c}23(0) \\
: \\
:\end{array}$ & $\begin{array}{l}9(37.5 \%) \\
2(7.4 \%) \\
11(42.3 \%) \\
15(55.6 \%) \\
7(25.0 \%)\end{array}$ & $\begin{array}{l}4 \\
\vdots \\
\vdots \\
\vdots\end{array}$ & $\begin{array}{l}\mathbf{1}(14.3 \%) \\
\mathbf{1}(14.3 \%) \\
\mathbf{3}(42.9 \%) \\
\mathbf{3 ( 4 2 . 9 \% )} \\
\mathbf{2}(28.6 \%)\end{array}$ & : & $\begin{array}{c}4(21.1 \%) \\
25(26.3 \%) \\
30(31.6 \%) \\
10(52.6 \%) \\
4(20 \%)\end{array}$ & $\begin{array}{l}1 \\
\vdots \\
\vdots \\
\vdots\end{array}$ & $\begin{array}{l}0.529 \\
0.270 \\
0.882 \\
0.701 \\
1.000\end{array}$ \\
\hline $\begin{array}{c}\text { Comorbidities } \\
\qquad \begin{array}{l}\text { Diabetes } \\
\text { Hypertension } \\
\text { Cardiovascular } \\
\text { diseases }\end{array} \\
\end{array}$ & $\begin{array}{l}44(63.8 \%) \\
50(72.5 \%) \\
26(38.2 \%)\end{array}$ & 9 & $\begin{array}{c}15(75 \%) \\
14(70.0 \%) \\
8(40.0 \%)\end{array}$ & r & $\begin{array}{l}15(60.0 \%) \\
19(76.0 \%) \\
11(44.0 \%)\end{array}$ & rus & $\begin{array}{c}3(50.0 \%) \\
4(66.7 \%) \\
0(0 \%)\end{array}$ & $\vdots$ & $\begin{array}{l}11(61.1 \%) \\
13(65 \%) \\
7(41.2 \%)\end{array}$ & ì & $\begin{array}{l}0.407 \\
0.743 \\
0.178\end{array}$ \\
\hline $\begin{array}{l}\text { Quick COVID severity Index* } \\
\text { Low-risk group } \\
\text { Low-intermediate risk } \\
\text { group } \\
\text { High-intermediate } \\
\text { risk group } \\
\text { High-risk group }\end{array}$ & $\begin{array}{c}20(35.7 \%) \\
14(25 \%) \\
22(28.2 \%)\end{array}$ & & $\begin{array}{c}0 \\
5(29.4 \%) \\
2(11.8 \%) \\
10(58.8 \%)\end{array}$ & v & $\begin{array}{c}0 \\
7(33.3 \%) \\
7(33.3 \%) \\
7(33.3 \%)\end{array}$ & $\Lambda$ & $\begin{array}{c}0 \\
3(75 \%) \\
0(0 \%) \\
1(25 \%)\end{array}$ & $r$ & $\begin{array}{c}0 \\
5(31.3 \%) \\
5(31.3 \%) \\
6(37.5 \%)\end{array}$ & 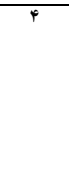 & 0.482 \\
\hline $\begin{array}{l}\text { Death } \\
\text { ICU care }\end{array}$ & $\begin{array}{l}40(52.6 \%) \\
34(44.7 \%)\end{array}$ & & $\begin{array}{c}18(78.3 \%) \\
14(60.86 \%)\end{array}$ & & $\begin{array}{c}20(71.4 \%) \\
16(57.14 \%)\end{array}$ & & $\begin{array}{c}0(0 \%) \\
2(33.33 \%)\end{array}$ & & $\begin{array}{c}2(10.5 \%) \\
2(10.52 \%)\end{array}$ & & $\begin{array}{l}<0.001 \\
<0.001\end{array}$ \\
\hline
\end{tabular}

DM: Diabetes mellitus; HTN: Hypertension; CD: Cardiac disease

Comparison of blood, inflammatory, biochemical and clinical indices between the four groups in patients shows that $\operatorname{LDH}(\mathrm{P}=0.022)$, AST $(\mathrm{P}=0.038)$ and $\operatorname{ALT}(\mathrm{P}=0.004)$ indices were significantly different between groups of patients. 
Table 2. Laboratory data in admission and discharge of COVID-19 patients

\begin{tabular}{|c|c|c|c|c|c|c|c|c|c|}
\hline variable & $\begin{array}{c}\text { Non dialysis } \\
\text { CKD } \\
(\mathbf{n}=\mathbf{2 3}) \\
\end{array}$ & & $\begin{array}{c}\text { CKD on } \\
\text { maintenance } \\
\text { dialysis }(n=28)\end{array}$ & & $\begin{array}{c}\text { Dialysis in covid } \\
\text { patients }(n=7)\end{array}$ & & $\begin{array}{c}\text { KT } \\
(\mathrm{N}=\mathbf{2 0})\end{array}$ & & $\begin{array}{c}\text { p- } \\
\text { value }\end{array}$ \\
\hline $\begin{array}{l}\text { CBC on admission: median (IQR) } \\
\text { RBC: } \\
\text { Hct: } \\
\text { Hb: } \\
\text { PLT: } \\
\text { WBC: } \\
\text { Neut: } \\
\text { Lymph: } \\
\text { Infection-related indices } \\
\text { ESR } \\
\text { CRP } \\
\text { Biochemical } \\
\text { Alb } \\
\text { Troponin } \\
\text { LDH } \\
\text { CPK } \\
\text { Urea } \\
\text { Cr } \\
\text { AST } \\
\text { ALT } \\
\text { Bil total } \\
\text { Bil direct }\end{array}$ & $\begin{array}{l}3.8(3.0-4.7) \\
33.20(27.5-38.5) \\
9.40(8.50-12.50) \\
205.0(127.0-253.0) \\
9.50(6.90-12.90) \\
80.0(72.75-92-75) \\
14.5(5.0-22.25) \\
\\
50.0(16.50-83.50) \\
43.10(33.0-55.25) \\
\\
3.0(2.75-3.4) \\
0.023(0.005-0.80) \\
591(433.0-1354.0) \\
124(67-451) \\
124.5(56-212.5) \\
3.79(2.39-8.10) \\
40.5(21.25-71.5) \\
32(19-74.5) \\
0.8(0.55-1.65) \\
0.2(0.2-0.4)\end{array}$ & $\begin{array}{l}1 . \\
a \\
1 . \\
r \\
1 \\
\dot{r} \\
r \\
\dot{1} \\
1 \\
\dot{r} \\
r \\
r\end{array}$ & $\begin{array}{l}4.13(3.3-4.57) \\
36.05(33.22-39.75) \\
11.15(9.65-12.87) \\
192.0(116.0-289.0) \\
8.45(6.55-11.95) \\
85.0(79.0-87.0) \\
14.0(10.0-17.0) \\
\\
30.50(20.25-72.25) \\
38.0(21.0-47.0) \\
\\
2.8(2.5-3.35) \\
0.37(0.007-0.258) \\
625(490-877) \\
118.5(44-352.25) \\
108.5(63-176) \\
2.79(1.93-5.45) \\
28(17-74) \\
21(11-75) \\
0.75(0.47-1.1) \\
0.2(0.2-3.25)\end{array}$ & 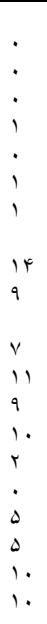 & $\begin{array}{l}3.9(3.42-4.42) \\
33.10(30.10-35.32) \\
10.15(9.25-10.75) \\
289(217.0-411.5) \\
7.45(6.20-9.62) \\
77.0(75.0-82.0) \\
18.0(13.0-19.50) \\
\\
64.50(51.0-78.0) \\
42.5(5.87-60.0) \\
3.4(3.15-3.57) \\
0.023(0.001-0.428) \\
329(266.0-483.0) \\
42(41.5-134.5) \\
95(50-119) \\
3.07(1.98-5.31) \\
13(12-19) \\
8(3.25-9) \\
0.8(0.5-1.1) \\
0.15(0.1-0.2)\end{array}$ & $\begin{array}{l}r \\
r \\
r \\
r \\
1 \\
1 \\
r \\
r \\
0 \\
0\end{array}$ & $\begin{array}{l}3.8(3.10-3.27) \\
35.65(28.95-38.07) \\
10.85(8.92-12.65) \\
159.0(124-221) \\
7.85(4.85-10.10) \\
80.0(75.75-89.0) \\
16.0(7.50-20.0) \\
\\
30.0(26.0-57.0) \\
38.0(14.25-53.42) \\
\\
3.2(3-3.9) \\
0.025(0.012-0.75) \\
447.5(353.25-584.5) \\
166(70-351.5) \\
101(83.25-149) \\
3.9(2.79-6.48) \\
26.5(18.75-39.25) \\
15.5(11.5-35) \\
0.7(0.5-2.3) \\
0.2(0.15-1)\end{array}$ & 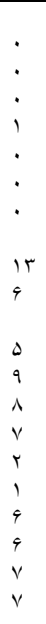 & $\begin{array}{l}\cdot / \Delta V Y \\
\cdot / Y Y q \\
\cdot / T \cdot 1 \\
0.129 \\
\cdot / \Delta \cdot r \\
\cdot / \Delta Y^{4} \\
\cdot / 944 \\
\\
\cdot / V Y r \\
\cdot / 4 \cdot 9 \\
\\
. / 19 \\
0.674 \\
0.022 * \\
0.241 \\
0.592 \\
0.64 \\
0.038^{*} \\
0.004 * \\
0.903 \\
0.515\end{array}$ \\
\hline $\begin{array}{l}\text { Vital signs } \\
\text { Temperature } \\
\text { RR } \\
\text { PR } \\
\text { Systolic BP }(\text { Mean } \pm \text { SD) } \\
\text { Diastolic BP }(\text { Mean } \pm \text { SD) } \\
\text { O2 Sat } \\
\end{array}$ & $\begin{array}{l}37(36.5-37.5) \\
19(17-26) \\
85(80-92) \\
121.95+\_26.36 \\
72.57+\_16.16 \\
87.5(85.25-94.25)\end{array}$ & $\begin{array}{l}2 \\
6 \\
0 \\
2 \\
2 \\
3 \\
\end{array}$ & $\begin{array}{l}37(36.8-37) \\
18(16.5-24) \\
82(80-93.5) \\
126.2+\_34.48 \\
74.39+\_15.47 \\
90(82-94.5) \\
\end{array}$ & $\begin{array}{l}2 \\
7 \\
2 \\
4 \\
5 \\
3 \\
\end{array}$ & $\begin{array}{l}36.5(36.15-36.67) \\
18(17.25-22.5) \\
82(70-90) \\
133.66+\_20.94 \\
76.33+\_10.32 \\
95(93.75-97) \\
\end{array}$ & $\begin{array}{l}1 \\
3 \\
0 \\
1 \\
1 \\
1\end{array}$ & $\begin{array}{l}37.1(36.65-37.45) \\
18(17.25-21) \\
86(86-99.9) \\
123.73+\_27.82 \\
78.15+\_17.98 \\
90(84.25-93.75) \\
\end{array}$ & $\begin{array}{l}3 \\
4 \\
0 \\
1 \\
1 \\
0\end{array}$ & $\begin{array}{l}0.033 \\
0.731 \\
0.859 \\
0.272 \\
0.427 \\
0.073 \\
\end{array}$ \\
\hline
\end{tabular}

Ad: Admission; Dis: Discharge; Alb=albumin, Trop=troponin; $\mathrm{LDH}=$ lactate dehydrogenase; $\mathrm{Cr}=\mathrm{creatinine}$; ICU=intensive care unit;

According to the results in Table 3, Unilateral ground glass opacity (GGO) in the radiological findings of the Non dialysis CKD group was significantly $(\mathrm{P}=0.50)$ higher than the other groups. However, other radiological indices did not differ significantly between different groups. On the other hand, no significant difference was observed in the type of drug used by the groups.

Table 3. Radiologic findings and vital signs

\begin{tabular}{|c|c|c|c|c|c|c|c|c|c|}
\hline & $\begin{array}{l}\text { Non dialysis } \\
\text { CKD }(n=23)\end{array}$ & 焉兽 & $\begin{array}{c}\text { CKD on } \\
\text { maintenance } \\
\text { dialysis }(n=28)\end{array}$ & 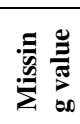 & $\begin{array}{c}\text { Dialysis in } \\
\text { COVID-19 } \\
\text { patients }(n=7)\end{array}$ & 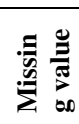 & $\begin{array}{l}\mathbf{K T} \\
(\mathrm{N}=20)\end{array}$ & $\mathbf{T}(\mathbf{M})$ & $\begin{array}{c}\text { p- } \\
\text { value }\end{array}$ \\
\hline $\begin{array}{c}\text { Radiologic findings } \\
\text { Unilateral GGO } \\
\text { Bilateral GGO } \\
\text { Pleural effusion } \\
\text { Collapse } \\
\text { Consolidation } \\
\text { Emboli } \\
\text { Band }\end{array}$ & $\begin{array}{l}6(54.5 \%) \\
5(45.5 \%) \\
5(45.5 \%) \\
1(9.1 \%) \\
0(0 \%) \\
0(0 \%) \\
1(9.1 \%)\end{array}$ & 12 & $\begin{array}{l}3(20 \%) \\
5(33.3 \%) \\
5(33.3 \%) \\
0(0 \%) \\
1(6.7 \%) \\
1(6.7 \%) \\
5(33.3 \%)\end{array}$ & 13 & $\begin{array}{l}1(20 \%) \\
3(60 \%) \\
4(80 \%) \\
0(0 \%) \\
0(0 \%) \\
0(0 \%) \\
0(0 \%)\end{array}$ & 2 & $\begin{array}{l}1(7.1 \%) \\
9(64.3 \%) \\
5(35.7 \%) \\
1(7.1 \%) \\
1(7.1 \%) \\
0(0 \%) \\
3(21.4 \%)\end{array}$ & 6 & $\begin{array}{l}0.050^{*} \\
0.383 \\
0.337 \\
0.621 \\
1.000 \\
1.000 \\
0.378\end{array}$ \\
\hline $\begin{array}{l}\text { Hydroxyqloroquine } \\
\text { Kaletra } \\
\text { INF } \\
\text { Anibiotics }\end{array}$ & $\begin{array}{l}20(87 \%) \\
12(52.2 \%) \\
2(8.7 \%) \\
22(95.7 \%)\end{array}$ & 0 & $\begin{array}{l}20(76.9 \%) \\
17(65.4 \%) \\
0(0 \%) \\
26(100)\end{array}$ & 2 & $\begin{array}{l}7(100) \\
3(42.9 \%) \\
0(0 \%) \\
7(100)\end{array}$ & 0 & $\begin{array}{l}19(95 \%) \\
5(25 \%) \\
0(0 \%) \\
20(100)\end{array}$ & 0 & $\begin{array}{l}0.283 \\
0.054 \\
0.332 \\
0.658\end{array}$ \\
\hline
\end{tabular}

Ggo=ground glass opacity, GCS=Glasgow coma scale 


\section{Discussion}

COVID-19 can cause a variety of symptoms in patients. And these clinical symptoms have different severity and nature depending on the history of underlying diseases, physiology and severity of infection in each patient. The results indicate that in this study the most common symptom in all patients was dyspnea. Also, dyspnea was the most common symptom in all patients on dialysis too, who were on maintenance dialysis or underwent dialysis following COVID-19. A previous study including five patients on hemodialysis with COVID-19 revealed that diarrhea and non-respiratory symptoms were the most common symptoms [15]. Another case report similarly reported that nausea and vomiting were the first symptoms of on dialysis COVID-19 patients [16]; however, in this study, the prevalence of gastrointestinal symptoms was only 25\%. Also, in patients with a history of a kidney transplant, 52.6\% had dyspnea while the study of Akaline et al. declares that, the initial symptom in these patients was fever [17]. However, given the nature and target tissue of the COVID-19 infectious agent, the prevalence of respiratory disorders can be predictable.

Contrary to the previous COVID-19 studies, in this study there were more women $(68.8 \%)$ than men $(31.2 \%)$ [18-21]. However, looking at the mortality rate of patients, it can be seen that the number of deaths in women $(52.8 \%)$ in the study was more than men $(44 \%)$ which according to the changes in sex hormone levels among female patients with end-stage renal disease, these differences can be justified [22].

Based on present study, $89.7 \%$ of patients had a history of underlying diseases. Most patients with severe conditions had diabetes, hypertension, and coronary diseases; which is aligned with the data that have been reported $[21,23]$ so that, Comorbidities in patients with kidney disease are risk factors for poor outcomes in COVID-19 [5].

This study declares that, even with the higher $\mathrm{O} 2$ saturation (mean=91.2) and normal respiratory rate (mean=16.71) in patients who underwent dialysis following COVID-19, the mortality rate was $80 \%$. While in patients without dialysis who had the lowest $\mathrm{O} 2$ saturation (mean $=86.73 \%$ ) and the highest respiratory rate (mean $=22.86$ ), the mortality rate was only $45.5 \%$.

In terms of laboratory data, the average level of creatinine in all patients was $4.37 \mathrm{mg} / \mathrm{dl}$ and between subgroups, patients on maintenance dialysis had the highest average creatinine level (5.74 $\mathrm{mg} / \mathrm{dl}$ ), contrary to the study of Ajaimy et al. which the median of creatinine in COVID-19 patients with kidney disease was $2 \mathrm{mg} / \mathrm{dl}$ [23]. It cannot be said that there is a strong correlation between albumin levels and patient outcome [24]. It is worth mentioning that in our study the mean LDH level in all patients was 667.058 U/L while in previous studies, the mean LDH level in COVID19 patients without kidney disease was $261 \mathrm{U} / \mathrm{L}$ and in patients with CKD was $264 \mathrm{U} / \mathrm{L}$ [13, 21]. On the other hand, in our study, the mean level of LDH in patients with a history of kidney transplantation at the time of admission was $815 \mathrm{U} / \mathrm{L}$ and at the time of discharge was $119.66 \mathrm{U} / \mathrm{L}$, which is much higher than the amount reported in the same study (mean LDH level=336 U/L) [17]. Also, in line with other studies, the LDH level was higher in patients who died and patients admitted to ICU which shows the correlation between the high level of LDH and poor outcome of patients [25].

Taking the patients' CT-Scan into consideration, align with other studies, bilateral ground-glass opacity was the most radiological finding [21, 23]. 
The implementation of the present study was accompanied by limitations that, for example, the evaluation of serum antibodies for COVID-19 (IgG and IgM) and hematologic tests have not been conducted to determine viremia have not been carried out which might have some useful information regarding patients' outcomes. Finally, our explanation may be restricted because of the small sample size.

\section{Conclusion}

According to the results, dyspnea was the most common symptom in patients in this study, while the levels of LDH, AST and ALT had the most changes. Also, the most common finding on a shelf CT scan is bilateral dimming of the ground glass. Also, the most common finding on chest CTScan is bilateral ground-glass opacity. on the other hand, due to the number of deaths and ICU admissions, it can be concluded that CKD is one of the important factors that can cause poor prognosis in COVID-19 patients. For this reason, it can be said that, it is important to evaluate clinical manifestations, radiologic findings, laboratory data, and outcome of COVID-19 patients with CKD, to establish a perspective for physicians to manage patients.

\section{Acknowledgments}

The authors appreciate all the doctors, nurses, and health care workers' effort involved in the diagnosis and management of our patients. We acknowledge the Medical Record Department of Labbafinezhad Hospital for coordinating data collection for CKD patients with COVID-19 infection. We thank Keivan Ranjbar and Dr. Reza Shahriarirad for revising the manuscript. We would also like to thank all patients involved in this study.

\section{Authors' contribution}

Y.S.K., S.K.M. contributed to the acquisition of data, drafting the article, and interpretation of data. S.S. contributed to the conception and design and interpretation of data. S.T and D.Y contributed to the initiation of the research and interpretation of data. A.Z. and M.M.D. contributed to the analysis and interpretation of data. S.A. contributed to drafting the article and revising it critically for important intellectual content. All authors have read and approved the final version of the manuscript.

\section{Funding}

No funding was obtained for this work.

\section{Availability of data and materials}

Data supporting the results reported in the article can be found by academic researches by sending an email to the corresponding author at dr.shsali@gmail.com.

\section{Ethics approval and consent to participate}

This research has been approved by the Ethics Committee of Shahid Beheshti University of Medical Sciences with the approval code IR.SBMU.REC.1399.018. Written informed consent was obtained from all participants or their proxies.

\section{Consent for publication}


All participants or their proxies gave written consent for their personal or clinical details along with any identifying images to be published in this study.

\section{Competing interests}

The authors declare that they have no competing interests. 


\section{References}

1. Estola T. Coronaviruses, a new group of animal RNA viruses. Avian diseases. 1970;14(2):330-6.

2. Hui DS, E IA, Madani TA, Ntoumi F, Kock R, Dar O, et al. The continuing 2019-nCoV epidemic threat of novel coronaviruses to global health - The latest 2019 novel coronavirus outbreak in Wuhan, China. Int J Infect Dis. 2020;91:264-6.

3. Paules CI, Marston HD, Fauci AS. Coronavirus Infections-More Than Just the Common Cold. Jama. 2020;323(8):707-8.

4. World Health Organization. WHO Coronavirus Disease (COVID-19) Dashboard. 2020. https://covid19.who.int/. Accessed 20 July 2020.

5. Guan WJ, Liang WH, Zhao Y, Liang HR, Chen ZS, Li YM, et al. Comorbidity and its impact on 1590 patients with COVID-19 in China: a nationwide analysis. Eur Respir J. 2020;55(5).

6. Wang B, Li R, Lu Z, Huang Y. Does comorbidity increase the risk of patients with COVID-19: evidence from meta-analysis. Aging. 2020;12(7):6049-57.

7. Sanyaolu A, Okorie C, Marinkovic A, Patidar R, Younis K, Desai P, et al. Comorbidity and its Impact on Patients with COVID-19. SN Comprehensive Clinical Medicine. 2020:1-8.

8. Joanne M. Bargman, Karl L. Skorecki. Chronic Kidney Disease. In: Jameson JL, Kasper DL, Longo DL, Fauci AS, Hauser SL, Loscalzo J, editors. Harrison's principles of internal medicine; 2018.p.2111-2121

9. Bikbov B, Purcell CA, Levey AS, Smith M, Abdoli A, Abebe M, et al. Global, regional, and national burden of chronic kidney disease, 1990-2017: a systematic analysis for the Global Burden of Disease Study 2017. The Lancet. 2020;395(10225):709-33.

10. Batle D, Soler MJ, Sparks MA, Hiremath S, South AM, Welling PA, et al. Acute Kidney Injury in COVID19: Emerging Evidence of a Distinct Pathophysiology. Journal of the American Society of Nephrology : JASN. 2020;31(7):1380-3.

11. Henry BM, Lippi G. Chronic kidney disease is associated with severe coronavirus disease 2019 (COVID19) infection. International urology and nephrology. 2020;52(6):1193-4.

12. Cheng Y, Luo R, Wang K, Zhang M, Wang Z, Dong L, et al. Kidney disease is associated with in-hospital death of patients with COVID-19. Kidney international. 2020;97(5):829-38.

13. Jung HY, Lim JH, Kang SH, Kim SG, Lee YH, Lee J, et al. Outcomes of COVID-19 among Patients on InCenter Hemodialysis: An Experience from the Epicenter in South Korea. J Clin Med. 2020;9(6).

14. World Health O. Clinical management of COVID-19: interim guidance, 27 May 2020. Geneva: World Health Organization. 2020. https://apps.who.int/iris/handle/10665/332196. Accessed 20 July 2020.

15. Wang R, Liao C, He H, Hu C, Wei Z, Hong Z, et al. COVID-19 in Hemodialysis Patients: A Report of 5 Cases. Am J Kidney Dis. 2020;76(1):141-3.

16. Ferrey AJ, Choi G, Hanna RM, Chang Y, Tantisattamo E, Ivaturi K, et al. A Case of Novel Coronavirus Disease 19 in a Chronic Hemodialysis Patient Presenting with Gastroenteritis and Developing Severe Pulmonary Disease. Am J Nephrol. 2020;51(5):337-42.

17. Akalin E, Azzi Y, Bartash R, Seethamraju H, Parides M, Hemmige V, et al. Covid-19 and Kidney Transplantation. New England Journal of Medicine. 2020;382(25):2475-7.

18. Badawi A, Ryoo SG. Prevalence of comorbidities in the Middle East respiratory syndrome coronavirus (MERS-CoV): a systematic review and meta-analysis. Int J Infect Dis. 2016;49:129-33.

19. Channappanavar R, Fett C, Mack M, Ten Eyck PP, Meyerholz DK, Perlman S. Sex-Based Differences in Susceptibility to Severe Acute Respiratory Syndrome Coronavirus Infection. J Immunol. 2017;198(10):4046-53.

20. Chen N, Zhou M, Dong X, Qu J, Gong F, Han Y, et al. Epidemiological and clinical characteristics of 99 cases of 2019 novel coronavirus pneumonia in Wuhan, China: a descriptive study. The Lancet. 2020;395(10223):50713.

21. Wang D, Hu B, Hu C, Zhu F, Liu X, Zhang J, et al. Clinical Characteristics of 138 Hospitalized Patients With 2019 Novel Coronavirus-Infected Pneumonia in Wuhan, China. JAMA. 2020;323(11):1061-9.

22. Ahmed SB, Ramesh S. Sex hormones in women with kidney disease. Nephrol Dial Transplant. 2016;31(11):1787-95.

23. Ajaimy M, Melamed ML. COVID-19 in Patients with Kidney Disease. Clin J Am Soc Nephrol. 2020;15(8):1087-9.

24. Lang J, Katz R, Ix JH, Gutierrez OM, Peralta CA, Parikh CR, et al. Association of serum albumin levels with kidney function decline and incident chronic kidney disease in elders. Nephrol Dial Transplant. 2018;33(6):986-92. 
25. Henry BM, Aggarwal G, Wong J, Benoit S, Vikse J, Plebani M, et al. Lactate dehydrogenase levels predict coronavirus disease 2019 (COVID-19) severity and mortality: A pooled analysis. Am J Emerg Med. 2020;38(9):17226.

26. Haimovich AD, Ravindra NG, Stoytchev S, Young HP, Wilson FP, van Dijk D, Schulz WL, Taylor RA. Development and Validation of the Quick COVID-19 Severity Index: A Prognostic Tool for Early Clinical Decompensation. Ann Emerg Med. 2020;76(4):442-453. 
Figures

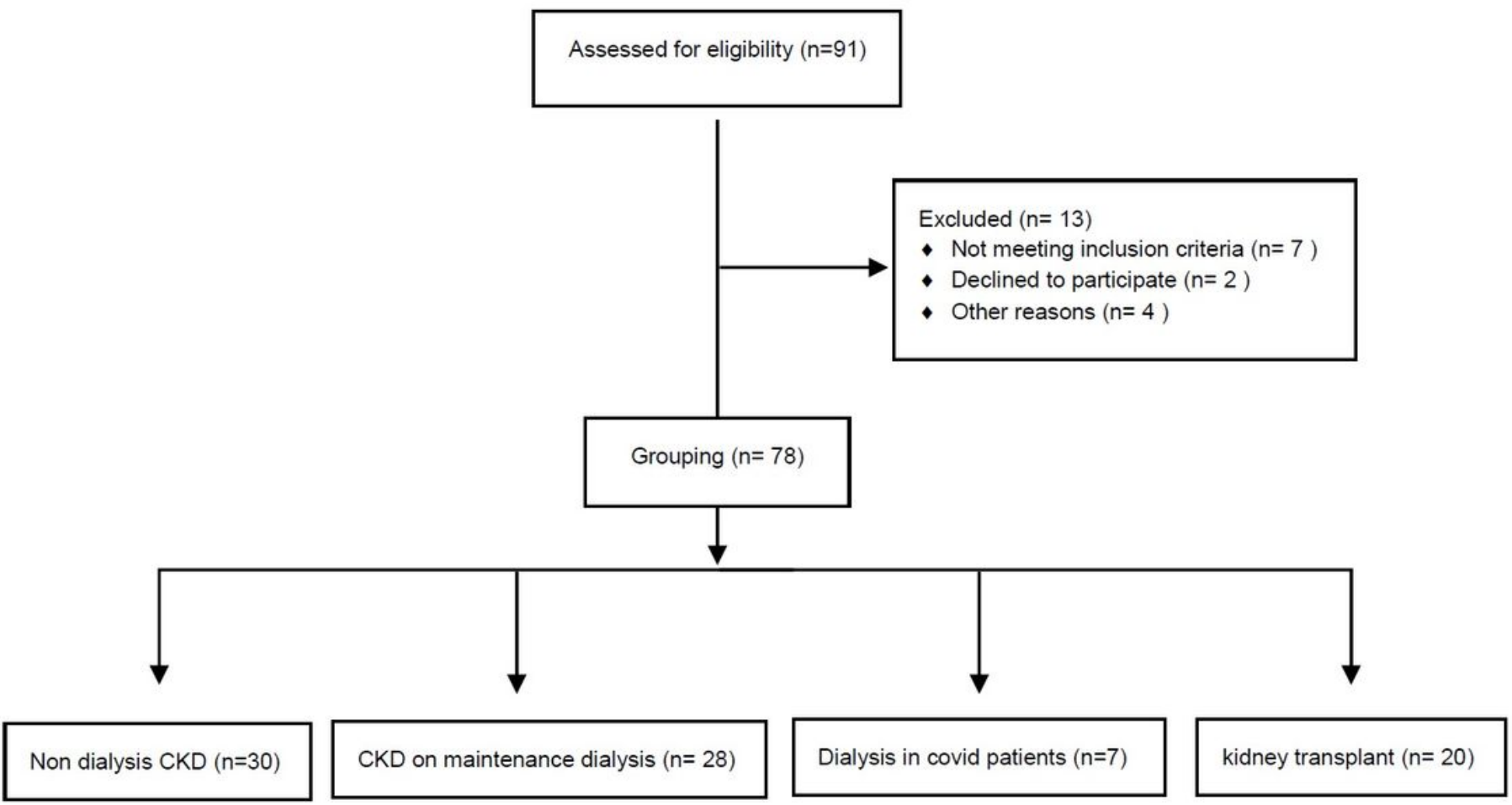

Figure 1

Consort diagram

\section{Supplementary Files}

This is a list of supplementary files associated with this preprint. Click to download.

- STROBEchecklistv4crosssectional.pdf 